developments which since have been made in the design and use of electrical apparatus for oil-well drilling and pumping have been tried out and perfected first in the California fields before being adopted elsewhere. This has been due not only to the field conditions encountered there, but also to the availability of dependable central station power service in all of the fields.

Of the tremendous connected horsepower in the oil industry in the United States, it is understood that only 7 per cent is electrical. In California alone there is 1,500,000 hp. installed, of which only 15 per cent is electrical. This indicates the potential possibilities for electrification. (A. I. E. E. Paper No. 31-128)

\section{Correlation of Induction-Motor Design Factors}

\author{
By Vaino Hoover ${ }^{3}$
}

\begin{abstract}
An analysis of stator resistance, wire size, horsepower rating, and air-gap density as a function of the flux per pole per unit-length of lamination stacking, stator slot shape and slot insulation, rotor diameter, and flux densities in the stator teeth and core, is given in this paper.

The usual method of design is to begin with the rotor radius, flux per pole, and ampere-conductors per inch of rotor circumference. The flux density in the air-gap is determined when the stator-tooth density and the ratio of slot pitch and tooth width are set. The depth of slot is determined by the ampereconductors per inch, and the cir. mils per ampere. The depth of stator core and the stator radius then are determined by setting the value of the flux density in the stator core. The relations of the rotor and stator radius, the width of slot and tooth, the depth of slot and core, the flux per pole, and the flux density, to each other and to the motor performance are quite vague. Therefore, to determine their best proportions is difficult unless many experimental data are available.

In this paper an attempt is made to determine the relation of these factors to each other, and to determine their proportions for the best design. Briefly outlined, the analysis is presented as follows: The area of the stator slot is developed as a function of the shape of the slot, and the area occupied by the slot insulation. The effect of the slot insulation on the net area of the stator slot is taken into account by using a corrected value for the stator radius. The area of the wire used for stator coils is developed as a function of the flux per pole. The stator resistance is expressed as a function of flux per pole, and slot shape. The rotor radius is determined by setting the ratio of the flux densities in the core and teeth. A sample calculation is made using this method of design for motors of from two to twelve poles. The maximum torque as a function of the flux densities and of the flux per pole is discussed. The effect of stator resistance on maximum torque is calculated and shows that the flux per pole used should be very nearly that for minimum stator resistance. Fifty-three equations are developed.
\end{abstract} (A. I. E. E. Paper No. 31 M 7 )

\section{A.C. Networks in Portland, Oregon}

$$
\text { By S. B. Clark }
$$

Essentially the full text of this paper was presented on pp. 644-647, Electrical Engineering, August, 1931. (A. I. E. E. Paper No. 31 M 2)

\section{The Mokelumne River Development of the Pacific Gas and Electric Company}

By E. A. Crellin

Essentially the full text of this paper is published on pp. 705-12, of this issue of Electrical Engineering. (A. I. E. E. Paper No. 31-130)

\section{Power Transmission and Distribution from the Mokelumne River Development}

\author{
By E. M. Wright ${ }^{5}$ and B. D. Dexter
}

Essentially the full text of this paper is published on pp. 713-18, of this issue of Electrical Engineering. (A. I. E. E. Paper No. 31-131)

\section{Tie-Line Control \\ of Interconnected Networks}

$$
\text { By T. E. Purcell6 and C. A. Powel7 }
$$

Operating experience with tie-line load regulators on the Pittsburgh, Pa. tie line interconnecting the Colfax Power Station of the Duquesne Light Company with the Springdale station of the West Penn Power Company is described in this paper. Equipment used, including tie-line load regulators, program load control, and a hydraulic speed changer also is described.

The prime requirements of a successful tie-line load regulator are that it must not respond to small transient load changes, but that it must respond to small sustained changes. Further, it must respond to large load changes whether temporary or sustained.

The program loading equipment mentioned is installed at the Colfax station to maintain the most economical division of load between the various generating units of that particular station. The principle of dividing all load increments proportionally between units in a steam station does not necessarily make for maximum efficiency. In the program equipment at Colfax load scheduling is based on turbine valve position rather than on generator output, thus maintaining each turbine at its most efficient valve opening regardless of the effect of the many variables which enter into the position of the valve with reference to the load.

The new hydraulic speed-changing device described is intended to reduce to a minmum, wear on the governor parts, and to offset the tendency for increased wear arising from the extremely frequent governor operation imposed by frequency control.

As a result of tests made jointly by the Duquesne Light Company and the West Penn Power Company, the following conclusions are reached:

1. Tie-line load regulators and program loading equipment have been developed to a commercial stage.

2. Tie-line load regulators on one system can be operated satisfactorily in conjunction with frequency regulators on a connected system.

3. Tie-line control may be used to reduce load fluctuations between interconnected systems. (A.I. E. E. Paper No. 31 -127) 